UDC: $371.3:: 811.111 ; 371.64 / .69$

\title{
SUBJECT CONTENT KNOWLEDGE TRANSFER
}

\author{
JOANNA KIC-DRGAS 1 \\ Koszalin University of Technology, \\ Poland
}

\begin{abstract}
Današnje promene u ekonomiji i tehnologiji utiču na strukturu i upotrebu jezika. Najvidljivije promene mogu se uočiti u oblasti engleskog jezika struke, odnosno jezika struke uopšte, koji karakteriše visoko specijalizovana podela jezika. Predmetno znanje, koje je ključno za ovu podelu, ima važnu ulogu u nastavi (engleskog) jezika struke. Stoga ovaj rad razmatra ulogu predmetnog znanja u nastavnom procesu i način na koji se ono predstavlja na ovim kursevima. Rad pruža rezultate istraživanja didaktičkih materijala koji se koriste u nastavi jezika struke. Osnovni zaključak istraživanja jeste da postoji deficit nastavnih materijala koji odgovaraju potrebama studenata, što ukazuje na to da je neophodno razviti i unaprediti materijale za specifičnu nastavu jezika struke.
\end{abstract}

Ključne reči: engleski jezik struke, jezik struke, podela jezika, predmetno znanje.

\section{INTRODUCTION}

The intense development and specialisation of different fields of science and economy worldwide have led to significant changes in language structure and usage. Globalisation, unification and internationalisation are just a few of the many processes that have made an enormous contribution to the very high diversification of languages. According to Grucza (2013a: 7), the higher the level of development in a certain society, the higher the level of language specialisation. Language specialisation is considered to be a huge challenge for the current field of linguistics because it requires not only knowledge about the functioning of a language in a particular domain, but often also a highly specific knowledge of the the discipline.

The following article focuses on the latter facet and how to incorporate it in ESP teaching. First, the article gives an overview of various approaches to ESP (English for Specific Purposes) /LSP (Language for Specific Purposes) teaching. Next, text as a source of subject content knowledge is discussed. Finally, the author focuses on the element

1 Kontakt podaci (Email):j.drgas@tlen.pl 
of knowledge in ESP/LSP in general and its application in teaching methodology. The article refers to research conducted by the author.

\section{LSP/ESP}

Deciding on one definition of LSP/ ESP is not an easy task because the meaning of the term has expanded tremendously in recent years. To illustrate the wide discrepancy between different points of view, several definitions are discussed below. Moreover, to gain a complete picture of the subject, the research results presented here have been provided by scientists representing different nationalities.

According to Hutchinson and Waters (1987), ESP teaching should not be considered as a product, but as a certain approach to the language teaching process. The most important participant of the process is the learner: "The foundation of ESP is a simple question: Why does this learner need to learn a foreign language?" Further, "all decisions as to content and method are based on the learner's reason for learning" (Hutchinson/ Waters 1987: 19). Thus, the essence of ESP teaching is tailoring to the learners' needs. The factors of learners' age and level of language skills in the context of ESP are also mentioned by Dudley-Evans and St. John (1998: 2-4). The suggested division between absolute and variable characteristics of ESP makes an interesting contribution to the discussion of ESP. The quoted scientists take specific knowledge into consideration. In addition, the knowledge element also mentioned in terms of ESP teaching (being a part of ESP reflection) results in the modification of the teacher's role in ESP classes. Furthermore, ESP teaching is directly combined with the methodology of the concerned discipline. ESP does not exist in isolation, but is linked to a certain content. This sheds a new light on the way specific language teaching should be perceived. Douglas (2000: 2) concentrates his reflections on ESP by taking the similarities and differences between ESP and GE (General English) into account. What distinguishes ESP from more general language is "interaction between language knowledge and specific purpose content knowledge". The differentiation point in this description is again specific knowledge, which also refers to the teaching process. Similarly, Grucza (2002: 18) stresses that LSP uses phonemics, phonetics and grammar of natural languages, and its main task is to convey a very specialised message. Kastberg (2007:2) introduces the idea of 'knowledge communication' in the context of ESP, which means 'strategic communication'. "It is 'strategic', as it is deliberately goal-oriented, with the goal being understanding knowledge asymmetries. As 'communication', it is participative (interactive), and communicative 'positions' cover the (co-) construction of (specialised) knowledge." Likewise, the latest research done by Paltridge and Starfield (2013) shifts the meaning of ESP from language or learners themselves to the aspect of communication in the foreign language. "English for specific purposes refers to the teaching and learning of English as a second or foreign language where the goal of the learners is to use English in a particular domain" (Paltridge/Starfield 2013: 3). In the statement of Paltridge and Starfield (2013), an aspect of language pragmatics appears. Language teaching aims at communication, and this also needs to be considered in the field of ESP teaching, though the content of the conveyed message and the kind of discourse used differ a lot 
from General English. Louhila-Salminen (2002: 229) underlines the meaning of specific knowledge in the current world and classifies it as a category by itself: "for today's business professional it is not nearly enough to master "the four skills" of English. Instead, they will have to be literate in the various, rapidly changing business situations where their reading, writing, listening and speaking simultaneously contribute to their actions and reactions in the daily routine." In short, learner-centeredness, specific content, communication need and the new role of the teacher are features that complete the characteristics of modern ESP teaching.

\section{TEXT AS A SOURCE OF SUBJECT CONTENT KNOWLEDGE}

Throughout the modifications and changes of a language, one thing remains stable - text as a representative research sample and source of current knowledge about LSP. At this point it is worth defining what the specific language text is. The answer to this question is given by Hoffmann (1985: 233), who explains that a specific text is both an instrument and a result that comes into being by a specific productive activity. Text can consist of an indefinite number of logically, semantically and syntactically coherent sentences or phrases similar to sentences that reflect certain images in the heads of users. Additionally, the same text delivers information about the structure and features of the specific language. Without reference to the linguistic features of a language for a specific domain, the production of correct and understandable sentences in a professional context is not possible. A specific text conveys not only a linguistic message, but also includes specific content. This is why it is a measurable piece of information about language immersed in a specific context. Language does not exist in vacuum, and to learn LSP means also to observe certain structures in context. According to Roelcke (2010: 19), research on specific texts should also take a few more aspects into consideration. The scientist names the following aspects:

- sociological

- psychological

- semiotic and communicative

Sociological aspects are a significant part of professional life and coexistence in society. They also refer to the individual differences and statuses of language users. Roelcke (2010: 20) mentions the following examples of social aspects:

- age and sex of the participants,

- $\quad$ social status (symmetry in contacts between co-workers and asymmetry in contacts between supervisors and subordinates),

- professional status (in this category, intra- , inter- and extra- communication can be distinguished; intracommunication means communication between specialists working in the same line of business, intercommunication between specialists active in different industry lines and extracommunication between professionals and laymen),

- $\quad$ the level of intimacy between interlocutors. 
Psychological aspects are highly individualised aspects linked to particular skills. The following belong to this group:

- intellectual abilities (abstract or analytic way of thinking, imagination, creativity, etc.),

- linguistic competence (active and passive LSP vocabulary),

- situation-dependent psychological and physical states,

- motivation and intention of communication,

- scale of dependence connected with communication.

Semiotic and communicative aspects refer to the structure of conversation. Roelcke (2010: 22) draws attention to the following points to be considered within the group:

- the number of people taking part in communication,

- communication media (written, oral or via new media),

- special and temporal relationships (direct and indirect communication),

- $\quad$ presentation of and relationships between topics that come up in communication.

These aspects lead to the integration of LSP research. Baumann (1992) called the phenomenon 'integrative Fachtextlinguistik'. The above reflections about LSP/ESP structure show the interdisciplinary character of the field, in which the influences of psychology, sociology, grammar, speech act theory or even statistics can be found (see Baumann 1992: 183-184).

\section{SUBJECT CONTENT KNOWLEDGE IN ESP TEACHING}

The aforementioned definitions clearly show how significant the element of subject content knowledge in LSP/ESP theory is. This aspect concerns not only learners but also teachers preparing courses. In the second half of the article, the meaning and intensity of the knowledge element for both groups in ESP will be discussed.

\subsection{LEARNERS}

Subject content knowledge in LSP/ESP refers to learners' preparation to learn about particular processes in a foreign language. How much of the specific knowledge should the learner have to be able to understand the course content? Moreover, the second question that should be raised is what level of language knowledge the learner is expected to have to start an ESP/LSP course. The answer to the first question needs a short structure analysis of the learners group. According to Frendo (2005:1), there are three types of ESP learners in terms of experience: 'pre-experienced learners' (with no or very little knowledge of subject content), 'job-experienced' learners (who know certain processes from their professional practise) and the third group of 'general-businessexperienced' learners (who have some professional experience but want to learn ESP to move to another job). The characteristics presented by Frendo (2005) show explicitly that the structure of an ESP learner group is very inhomogeneous, which makes setting course objectives a considerable challenge for ESP teachers. Theoretically, learners' 
knowledge of subject content facilitates the learning process, but, as Frendo's division confirms, this does not have to be a rule in the ESP classroom. This has already been mentioned by Dudley-Evans and St. John (1998), who suggest that only intermediate or advanced students have enough language knowledge to identify a real context for the vocabulary and structures of the ESP classroom. The knowledge of GE (General English) is essential because LGP (Language for General Purposes) is the foundation for LSP, using its phonetics, phonology, grammar and semantics. In short, learners with insufficient language knowledge might have difficulties understanding specialised issues. In conclusion, there are two variable factors influencing learners' participation in the ESP class. One of them is subject content knowledge, and the second one is language knowledge. As acquaintance with a certain topic makes it easier to face that topic's course requirements, at least an intermediate knowledge of the language is obligatory for learners to follow the course objectives.

\subsection{TEACHERS}

Subject content knowledge refers to foreign language teachers as well. For them, conducting an ESP class necessitates becoming familiar with a new discipline. In the context of intensive specialisation and the evermore detailed diversification of ESP/LSP, this raises the question of who should teach ESP. Conducting an ESP course requires, on the one hand, good foreign language knowledge (e.g. specific vocabulary, grammar structures, etc.), and on the other hand, subject content knowledge (knowledge regarding the functioning of a certain discipline or processes of a particular field). The advantage of the fact that a foreign language teacher conducts an ESP/LSP course is directly linked to the teacher's education in linguistics (as a result of linguistic studies). Unfortunately, the majority of language departments in Poland do not exactly offer preparatory studies for teaching ESP/LSP. In some more popular fields (Business English, Legal English), subject content knowledge of language can be confirmed through with different kinds of language certificates. However, there are new or very specialised industry branches (that have a particular need for communication in a foreign language and its correct usage in specific contexts) in which access to the subject content knowledge is very limited. Furthermore, there are no textbooks covering the basic vocabulary of these specialised industry branches. Practising teachers or philology students can broaden their knowledge in different postgraduate courses, but they are usually offered only in the Polish language, which means learning only the theoretical background of the processes without taking specialised vocabulary in specific contexts into account. The second possible group of teachers (or language trainers) consists of practising specialists, who are a relatively fast-growing group. Graduates with an in-depth knowledge of a subject seem to be the appropriate choice for teachers of ESP because they are familiar with the specific subject and understand its processes. The drawback of this group can be a general lack of knowledge of the foreign language.

In conclusion, an ESP/LSP teacher does not have to be an expert in a particular field. However, the issue of a teacher's familiarity with a specific discipline is a dilemma that remains unsolved. Obviously, there is also a third group of teachers who simultaneously 
belong to both groups (e.g. with perfect foreign language knowledge and having completed studies connected with a particular subject), but this is a rare case.

\subsection{SUBJECT CONTENT KNOWLEDGE IN TEACHING PRACTISE}

The next field of reflection concerns the way subject content knowledge is presented in the foreign language classroom. Considering the fact that there are many different fields of ESP (some of them are new, some are a result of technological innovation), how subject content knowledge should be transferred is a very valid question. Later in the article, the author's research on this topic is presented.

\section{SUBJECT CONTENT KNOWLEDGE TRANSFER - RESEARCH DESCRIPTION AND DATA PRESENTATION}

The data presented below is only a fragment from the lengthy research conducted by the author in May 2013 on a group of 30 teachers of ESP courses at public universities (from the following departments: law, biology, medicine, informatics, biotechnology and economics) and in a private language school (economics, management) in the Poznań area. Teachers who participated in the survey were asked to name how they present subject content knowledge in ESP classes, and to explain why they had chosen particular materials or activities. The survey had an open-question format and was anonymous. Participants could choose more than one answer. The collected answers give an overview of the range of methods used by teachers of ESP classes in Poland.

\section{Structure of the surveyed group}

The figure below presents the structure of the group of teachers who participated in the survey.

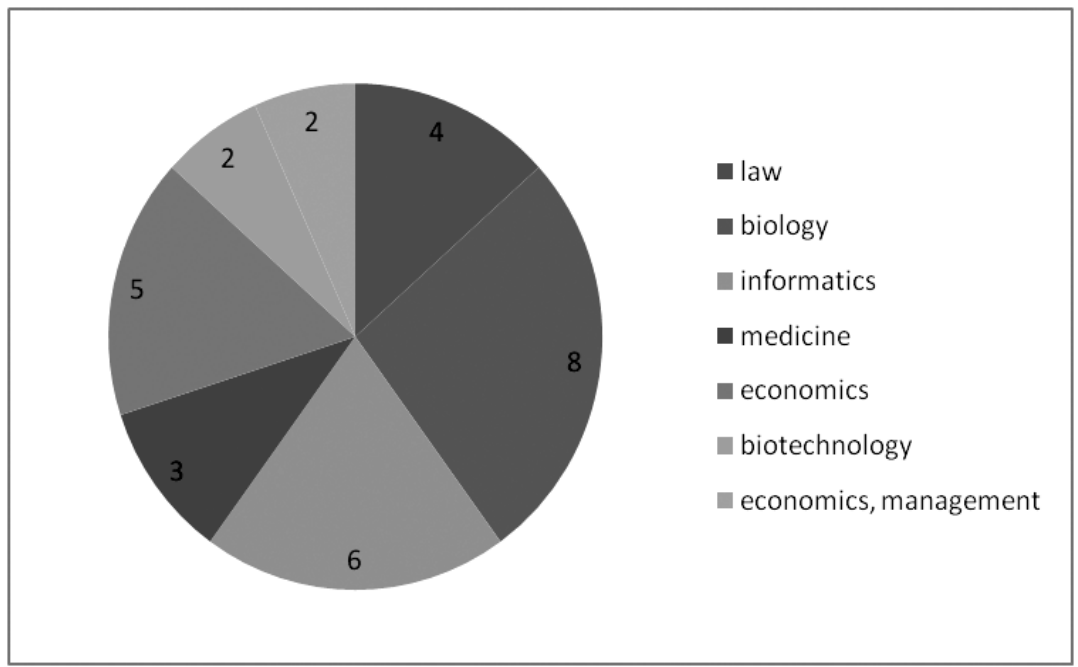


All surveyed teachers had an MA degree; their work experience is depicted in the diagram.

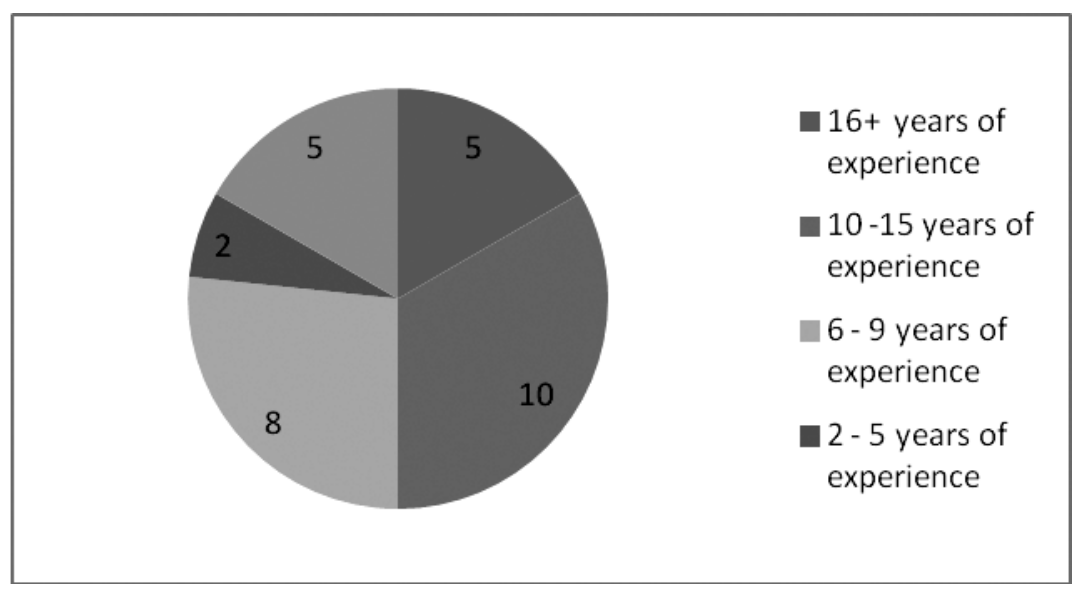

\section{Presentation of subject content knowledge}

The collected data are shown in the diagram.

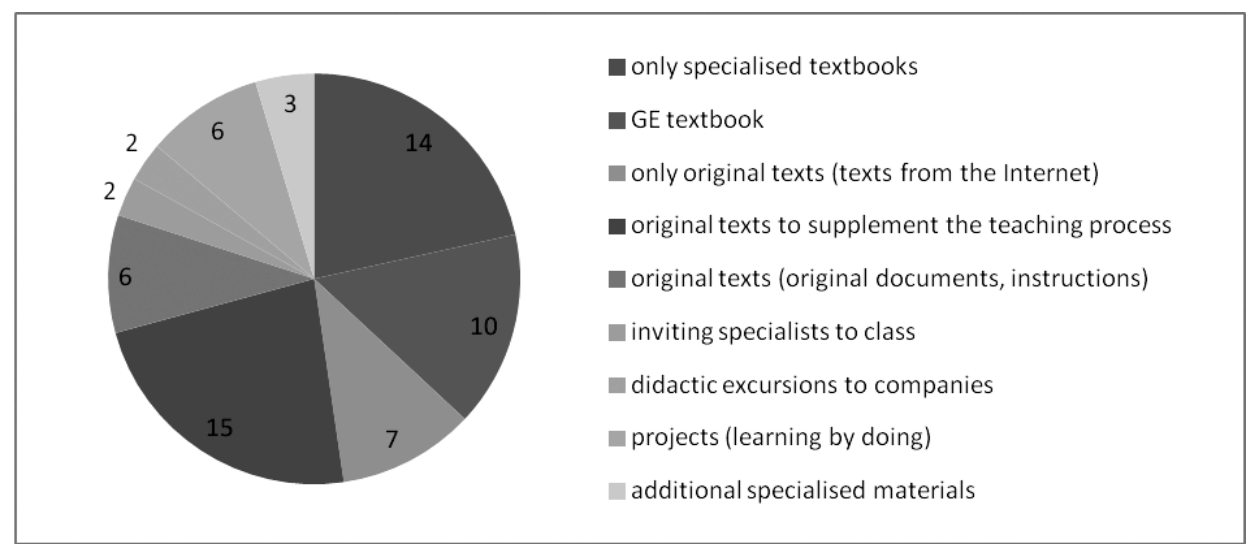

The collected data show that for almost $46 \%$ of the surveyed teachers, specialised textbooks are the main source of subject content knowledge in ESP classes (where no other materials are used to present the subject content knowledge). Furthermore, $23 \%$ of the teachers use original texts found on the Internet. Textbooks for teaching GE are used by $30 \%$ of the participants. Half of the participants use original texts to supplement the teaching process. A relatively small percentage ( 6 teachers) take advantage of original documents or instructions written in a company. Additional activities mentioned in the survey used to support ESP teaching are: projects, inviting specialists (practitioners) to present a particular topic to the class and didactic excursions to companies, factories or places connected with the subject content knowledge. 
The question of why the teachers chose certain materials was not answered by all teachers. There are only 22 answers to this question. The usage of textbooks designed to teach GE in the ESP class is explained by the fact that in some fields of ESP there are no adequate teaching materials on the market ( 8 answers). Some of the teachers admitted that they prefer working with a GE textbook and supplement their classes with additional specialised materials ( 3 answers). Five teachers answered that there is no need to introduce additional materials because specialised textbooks are welldesigned to meet their students' needs. One statement described the use of projects to broaden students' knowledge and make them do their own research on a topic by preparing a project.

To sum up, the complexity of the field of ESP influence show how subject content knowledge is presented in class. There seems to be a consistent need for the development of new materials on new aspects of developing science. Polish ESP teachers prefer implementing traditional methods to present subject content knowledge.

\section{CONCLUSION}

Subject content knowledge is how a language functions in a specific domain. The development of technology and scientific innovations contributes to the intense specialisation of domains, which in turn results in the creation of new ESP fields. The direct consequence of this process is an increasing demand for highly specialised ESP/ LSP courses to satisfy the need for communication in certain industries.

Learners participating in a specialised language course have different needs. Teaching language, which has already been emphasised in the following article, is responding to learners needs in reference to their learning aims and expectations. This is a very demanding task for teachers, taking into account that they have to gain new knowledge concerning subject content issues.

The majority of the teachers surveyed in the conducted research (46\%) stated that the main source of teaching materials for them are textbooks, while $23 \%$ use Internet sources to teach in specialised courses. The main conclusion of the research is that there is a deficit of adequate specific teaching materials tailored to the various needs of learners. An additional problem may be connected with the fact that for many language teachers, subject content knowledge is a new field in which they also may feel relatively insecure.

To sum up, subject content language teaching is a rapidly developing field that needs further in-depth research, especially in reference to teaching materials and methods.

\section{REFERENCES}

Baumann, K. D. 1992. Integrative Fachtextlinguistik. Tübingen: Gunter Narr Verlag. Douglas, D. 2000. Assessing Language for Specific Purposes. Cambridge: CUP. Dudley-Evans, T. 1998. Developments in English for Specific Purposes: A multi-disciplinary approach. Cambridge: CUP. 
Dudley-Evans, T. and M. J. St.John. 1998. Developments in English for Specific Purposes: A multidisciplinary approach. Cambridge: CUP.

Frendo, E. 2005. How to Teach Business English. Harlow: Pearson Longman.

Grucza, F. 2002. Języki specjalistyczne - indykatory/lub determinanty rozwoju cywilizacyjnego. In J. Lewandowski (ed.) Języki specjalistyczne. Problemy technolingwistyki. Warszawa: Katedra Języków Specjalistycznych, 9-26.

Grucza, S. 2013. Od lingwistyki tekstów do lingwistyki języków specjalistycznych. Warszawa: Wydawnictwo Naukowe Instytutu Kulturologii i Lingwistyki Antropocentrycznej, Uniwersytet Warszawski.

Hoffmann, L. 1985. Kommunikationsmittel Fachsprache. Eine Einfuhrung. Tübingen: Gunter Narr Verlag.

Hutchinson, T. and A. Waters. 1987. English for Specific Purposes: A learner-centered approach. Cambridge: CUP.

Kastberg, P. 2007. Knowledge Communication: The emergence of a third order discipline. In H. Gerzymisch-Arbogast (ed.) Kommunikation in Bewegung: Multimedialer und multilingualer Wissenstransfer in der Experten-Laien Kommunikation. Berlin: Peter Lang, 7-24.

Louhila-Salminen, L. 2002. The Fly's Perspective: Discourse in the Daily Routine of a Business Manager. English for Specific Purposes 21/3, 211-231.

Paltridge, B. and S. Starfield. 2013. The Handbook of English for Specific Purposes. New York: John Wiley \& Sons, Inc.

Roelcke, T. 2010. Fachsprachen. Berlin: Erich Schmidt Verlag.

\section{SUMMARY}

\section{SUBJECT CONTENT KNOWLEDGE TRANSFER}

Current economic and technological changes are influencing language structure and its usage. The most visible changes can be noticed in the field of ESP/LSP, which consists of a highly specialised division of language. Subject content knowledge, which is fundamental to this division, plays a very important role in ESP/LSP teaching. The following article discusses the impact of subject content knowledge on the teaching process and how it is presented in ESP/LSP courses. In the article, the results of the conducted survey referring to the didactic materials used in LSP teaching are presented. The main conclusion of the research is that there is a deficit of adequate specific teaching materials tailored to the various needs of learners. All the same, the desideratum concerning the need for developing teaching materials for specific content language teaching is made.

KEYWORDS: ESP, LSP, learner, language division, subject content knowledge.

(Original scientific paper received 07.01.2014; revised 17.12.2014; accepted 30.12.2014) 